\title{
Levels of Phonological Awareness, Working Memory, and Lexical Knowledge in Elementary School Children ${ }^{1}$
}

\author{
Heloisa Helena Motta Bandini² \\ Universidade Estadual de Ciências da Saúde de Alagoas, Maceió-AL, Brazil \\ Flávia Heloísa Santos \\ Universidade Estadual Paulista "Júlio de Mesquista Filho", Assis-SP, Brazil \\ Deisy das Graças de Souza \\ Universidade Federal de São Carlos, São Carlos-SP, Brazil
}

\begin{abstract}
Relationships between oral language, phonological awareness, and working memory have been empirically demonstrated, however, phonological awareness encompasses different abilities, assessed at different levels. The present study investigated the possible associations between specific phonological awareness abilities and phonological working memory in first-grade students. In the initial phase $(n=254)$, the study evaluated the abilities of phonological awareness and phonological working memory and found a high positive correlation between these abilities, thus confirming the findings of previous studies. The second phase $(n=12)$ evaluated the vocabulary of individuals who, in the initial phase, showed low or high working memory and phonological awareness scores. Students with low working memory and low phonological awareness capacities had low scores in expressive language abilities, suggesting that phonological working memory may have direct effects on lexical knowledge. These results contribute to the understanding of the relationships investigated in this study and have important implications for planning teaching strategies.
\end{abstract}

Keywords: working memory, language, reading, phonological awareness

\section{Níveis de Consciência Fonológica, Memória Operacional e Conhecimento Lexical em Escolares}

\begin{abstract}
Resumo: Relações entre linguagem oral, consciência fonológica e memória operacional têm sido demonstradas empiricamente, mas consciência fonológica engloba habilidades diferentes. Este artigo teve como objetivo investigar possíveis associações entre habilidades específicas de consciência fonológica e memória operacional fonológica em alunos do primeiro ano escolar. Na fase inicial $(n=254)$, o estudo avaliou habilidades de consciência fonológica e memória operacional fonológica e encontrou elevada correlação positiva entre ambas as habilidades, confirmando e estendendo resultados de estudos prévios. A segunda fase $(n=12)$ avaliou o vocabulário de indivíduos que obtiveram baixos ou altos escores em memória operacional e consciência fonológica na primeira fase. Os alunos com escores reduzidos de memória operacional e consciência fonológica obtiveram baixos escores em habilidades de linguagem expressiva, indicando que a memória operacional fonológica pode ter efeitos diretos sobre o conhecimento lexical. Esses resultados contribuem para a compreensão das relações investigadas e planejamento de estratégias de ensino.
\end{abstract}

Palavras-chave: memória operacional, linguagem, leitura, consciência fonológica

\section{Niveles de Conciencia Fonológica, Memoria Operativa y Conocimiento Lexical en Niños Escolares}

\begin{abstract}
Resumen: Las relaciones entre lenguaje oral, conciencia fonológica y memoria operacional han sido mostradas empíricamente, pero la conciencia fonológica engloba habilidades diferentes, mensuradas en diferentes niveles. El objetivo de este trabajo, conducido en dos estudios, fue investigar las posibles asociaciones entre las sub-clases de habilidades de conciencia fonológica, memoria fonológica de niños del primero año escolar. En el primero estudio $(n=254)$, fueron evaluadas las habilidades de conciencia fonológica y memoria fonológica, que mostraron fuerte correlación positiva. En el segundo estudio $(n=12)$, fueron realizados test de vocabulario en niños con bajos y altos escores en memoria operativa y conciencia fonológica. Los niños con puntuaciones bajas en memoria operativa fonológica y conciencia fonológica presentaran habilidades del lenguaje expresivo reducidas, indicando que la memoria operativa fonológica parece interferir directamente en el vocabulario. Los resultados contribuyen hacia la comprensión de las relaciones investigadas y afectan el plan de enseñanza.
\end{abstract}

Palabras clave: memoria operacional, lenguaje, lectura, conciencia fonológica

\footnotetext{
1 Support: National Council for Scientific and Technological Development (CNPq) - Processes N. 150313/2007-1 and N. 573972/2008-7; São Paulo Research Foundation (FAPESP) - Process N. 2008/57705-8. Acknowledgment: Temisson José dos Santos.

${ }^{2}$ Correspondence address:

Heloisa Helena Motta Bandini. Universidade Estadual de Ciências da Saúde de Alagoas. Rua Jorge de Lima, 113. Trapiche da Barra. CEP 57010-300. Maceió-AL, Brazil. E-mail: heloisabandini@gmail.com
}

Phonological awareness is a term used to describe the explicit and conscious ability to manipulate and segment speech to the level of phonemes (Kibby, 2009; Lundberg, Frost, \& Petersen, 1988), which means that the individual can abstract sound units with different extensions and recognize them in new words and even produce new words. Lundberg 
et al. (1988) proposed a categorization of phonological awareness abilities into three levels according to the order of complexity: (a) suprasegmental abilities, involving tasks such as judging whether words have the same initial or final sound, (b) syllabic abilities, including tasks such as segmenting words into syllables and adding or removing syllables from words, and (c) phonemic abilities, involving tasks of segmenting and recomposing words based on their constituent phonemes.

Evolutive differences in the phonological awareness tasks have not been fully elucidated, however, some evidence indicates reciprocal influences between phonological awareness abilities and learning to read and write, that is, as phonological awareness is a prerequisite for learning to read and write (McDowell, Lonigan, \& Goldstein, 2007; Mota \& Guimarães, 2011; Peeters, Verhoeven, de Moor, \& van Balkom, 2009), the phonological awareness abilities can also be improved and expanded by exposure of the individual to being taught to read and write (Bernardino Junior, Freitas, Souza, Maranhe, \& Bandini, 2006; Freitas, 2008).

The relationship between phonological awareness and phonological working memory is also important for the development of language. The primary function of the phonological working memory is to temporarily store unfamiliar sounds or the sound structures of new words as the basis for the establishment of lexical representations that gradually form and extend the vocabulary (Santos, Bueno, \& Gathercole, 2006). The most influential model of working memory describes it as being composed of four subsystems: the phonological loop, the visuospatial sketchpad, the central executive and the episodic buffer (Baddeley, 2003; Gathercole, 1998).

The phonological loop is responsible for processing verbal material and is subdivided into two components: the phonological store, which retains the phonological representations of the stimulus language, and the subvocal rehearsal, which is an articulation mechanism that has the function of remembering the phonological information. This information processing between the phonological store and the subvocal rehearsal is carried out in real time and is considered an important cognitive component for the acquisition and development of language (Baddeley, 2003).

The visuospatial sketchpad is responsible for the processing of visuospatial material and is also subdivided into two subcomponents: the visual store, which stores visual information, and a spatial mechanism, which has a visual reverberation function, keeping the visual information contained in the store active. As with the phonological loop, the information processing of these two subcomponents of the visuospatial sketchpad is carried out in real time and is strongly linked to the planning of motor abilities, such as speech for example. The central executive is responsible for coordinating all the actions of the short-term stores, retrieving permanent information in the long-term memory and performing mental arithmetic activities. Finally, the episodic buffer consists of a multidimensional representation system the function of which is to integrate the representations of the other components to the long-term memory into a unitary representation (Baddeley, 2003).

The phonological working memory constitutes an important cognitive component for the acquisition and development of oral language (Baddeley, 2003; Engel, Santos, \& Gathercole, 2008). In this context, researchers such as Alloway, Gathercole, Willis and Adams (2004) suggest that phonological awareness is not only affected by the tasks of reading and writing, but also by the development of the working memory abilities and by the refinement of other language abilities, in particular vocabulary, which has been confirmed by various studies (Fukuda et al., 2010; Kibby, 2009; Koo, Crain, LaSasso, \& Éden, 2008; Schuchardt, Maehler, \& Hasselhorn, 2008; Swanson, Zheng, \& Jerman, 2009).

Oakhill and Kyle (2000) demonstrated associations between the working memory abilities, both storage and processing demands, and two of the phonological awareness abilities (phoneme deletion and sound categorization). The authors concluded that working memory is crucial to the performance of phonological awareness tasks and that phonological awareness can be considered a ability with several distinct levels, which is consistent with the proposal of Lundberg et al. (1988).

The relationship between phonological awareness, phonological working memory and vocabulary development is well documented in the literature. However, the studies presented investigated only some of the phonological awareness abilities, such as rhymes and alliterations (Alloway et al., 2004), deletion of phonemes and rhymes (Oakhill \& Kyle, 2000), rhymes (Holliman, Wood, \& Sheehy, 2010), with the evaluations being varied regarding the nature of the task required in each phonological awareness or phonological working memory evaluation test. For this reason it is important to establish evaluation standards for each language, considering a broad set of abilities and tasks, as observed in the studies of Chiappe, Glaeser and Ferko (2007) and Rispens and Parigger (2010).

Considering that phonological awareness abilities may present different levels of development (syllabic and suprasegmental abilities develop prior to the phonemic abilities) and that these abilities can present different levels of reciprocal interference with the phonological working memory abilities, the present study aimed to investigate the relationships between these processes considering, in the evaluation, the set of abilities identified as phonological awareness components (Capovilla \& Capovilla, 1998; Lundberg et al., 1988). Study 1 investigated possible associations between specific phonological awareness abilities and phonological working memory in students of the first school year. Study 2 verified the mastery of expressive oral language of the participants in terms of levels of phonological awareness and phonological working memory. 


\section{Method - Study 1}

\section{Participants}

The sample was composed of 254 children (127 boys and 127 girls), aged between 5 years and 10 months and 6 years and 11 months $(M=6$ years and 2 months, $S D=3$ months), students of the first year of elementary education of a public school.

\section{Instruments}

Phonological Awareness Test, (Capovilla \& Capovilla, 1998), which aims to determine the ability of children to manipulate the sounds of the speech. The test consists of ten subtests, two for the evaluation of suprasegmental abilities (rhyme and alliteration), four for the evaluation of syllabic abilities (syllabic synthesis, segmentation, manipulation and transposition) and four for the evaluation of phonemic abilities (phonemic synthesis, segmentation, manipulation and transposition). Each subtest contains six items: two of training and four of evaluation. The results are analyzed through the frequency of correct responses: each correct response is worth one point (maximum 40 points). The levels of phonological awareness are estimated by the overall total points (the more points, the more accurate the abilities). A detailed description of the tasks, the instructions for their implementation, and the psychometric properties of this test can be found in Capovilla and Capovilla (1998).

Brazilian Repetition of Pseudowords Test (BCPR) (Santos $\&$ Bueno, 2003) aims to evaluate the phonological working memory abilities. It consists of 40 pseudowords (stimuli) with four different extensions, ten stimuli for each extension: two, three, four and five syllables. The assessor says aloud each of the stimuli of the list; the task of the student is to repeat the word. The results are analyzed through the frequency of correct responses, each correct response being worth one point (maximum 40 points). The levels of phonological working memory are estimated by the overall total points: The more points, the more accurate the phonological working memory ability. The psychometric properties of this test can be found in Santos and Bueno (2003).

Forward and Backward Digit Span Test of the WISC III intelligence scale (Wechsler, 1991), which aims to evaluate components of working memory: the phonological loop (direct order) and the central executive (reverse order). The digits are presented orally, starting with two digits and progressively increasing with every correct answer of the participant. The test is divided into two stages. In the first, the child must repeat the digits in the same order in which they are presented, in the second, the child must repeat them in reverse order. In both stages, the test is terminated after two consecutive incorrect repetitions by the child. The final test result is a score (called span) for each stage and the higher the value of the span, the greater the memory capacity.

\section{Procedure}

Data collection. The children were evaluated individually by the researcher, in a single session during the class period, in a quiet room provided by the school in which they studied. The three tests were given in the sequence they are presented below. Between one test and another, a short break was held to prepare the situation or material, during which the researcher talked with the child about trivial aspects of daily life.

Data analysis. The results were analyzed from two different aspects: first the phonological awareness abilities, the short-term memory for digits and repetition of pseudowords were analyzed in isolation, then correlations were drawn between the values of the total scores of each cognitive test used. For this second step, the Kolmogorov-Smirnov and ShapiroWilk normality tests were applied. The scores presented a non-normal distribution (Kolmogorov-Smirnov, $p<.01$ ). For this reason the nonparametric bivariate correlation test was used, observing the degree of linear relationship through the Spearman correlation coefficient $(p<.05)$.

\section{Ethical Considerations}

The procedures of Study 1, as well as those of Study 2, were approved by the Human Research Ethics Committee of the Universidade Federal de São Carlos (protocol No. 327) and executed with the care necessary to ensure the well-being of the participants and to avoid their exposure to risks of any kind.

\section{Results and Discussion}

The aim of Study 1 was to investigate possible associations between different levels of phonological awareness and phonological working memory in children at the beginning of the literacy process. The phonological awareness data were analyzed by phonological awareness ability categories: suprasegmental, syllabic and phonemic (Lundberg et al., 1988) and the by the total score of phonological awareness evaluated through the Phonological Awareness Test. Table 1 presents the mean scores obtained by the participants in the categories, in the tasks, and in the test total.

The table shows that the participants achieved high performance in the tasks related to the syllabic and suprasegmental abilities, demonstrating that children between 5 and 6 years of age already have a good mastery of these abilities. However, the mean scores obtained by the participants in the phonemic tasks represent less mastery, with a maximum score around half that of the scores obtained in the other tasks. These results confirm those obtained by Bernardino Junior et al. (2006) and Lundberg et al. (1988) for children of the same age, and therefore strengthen the notion of hierarchy in the acquisition of the phonological awareness levels. The design of Study 2 did not allow the conclusion to be made regarding whether the suprasegmental abilities precede the syllabic abilities or vice versa. However, clearly, these two abilities are more developed in children at the beginning of the literacy process than the phonemic abilities. 
Table 1

Mean Scores of the Phonological Awareness Test $(n=254)$, Standard Deviation, Median, Maximum and Minimum Scores, and Mean of Total Correct Responses and Specific Tasks in Study 1

\begin{tabular}{|c|c|c|c|c|c|c|}
\hline & Mean & $\begin{array}{c}\text { Standard } \\
\text { Deviation }\end{array}$ & Median & Maximum & Minimum & $\begin{array}{l}\text { Mean of Correct } \\
\text { Responses }(\%)\end{array}$ \\
\hline \multicolumn{7}{|l|}{ Abilities by Class } \\
\hline Suprasegmental & 6.25 & 2.35 & 8.0 & 8.0 & 0.0 & 78 \\
\hline Syllabic & 12.96 & 3.84 & 15.0 & 16.0 & 0.0 & 81 \\
\hline Phonemic & 7.39 & 5.17 & 8.0 & 16.0 & 0.0 & 46 \\
\hline \multicolumn{7}{|l|}{ Specific Abilities: Suprasegmental } \\
\hline Rhyme & 3.1 & 1.2 & 4.0 & 4.0 & 0.0 & 77.5 \\
\hline Alliteration & 3.2 & 1.2 & 4.0 & 4.0 & 0.0 & 80 \\
\hline \multicolumn{7}{|l|}{ Specific Abilities: Syllabic } \\
\hline Syllabic Synthesis & 3.6 & 1.0 & 4.0 & 4.0 & 0.0 & 90 \\
\hline Syllabic Segmentation & 2.9 & 1.6 & 4.0 & 4.0 & 0.0 & 72.5 \\
\hline Syllabic Manipulation & 2.5 & 1.8 & 4.0 & 4.0 & 0.0 & 62.5 \\
\hline Syllabic Transposition & 2.6 & 1.7 & 4.0 & 4.0 & 0.0 & 65 \\
\hline \multicolumn{7}{|l|}{ Specific Abilities: Phonemic } \\
\hline Phonemic Synthesis & 1.9 & 1.9 & 2.0 & 4.0 & 0.0 & 47.5 \\
\hline Phonemic Segmentation & 0.2 & 0.8 & 0.0 & 4.0 & 0.0 & 5 \\
\hline Phonemic Manipulation & 1.9 & 1.8 & 2.0 & 4.0 & 0.0 & 47.5 \\
\hline Phonemic Transposition & 0.2 & 0.8 & 0.0 & 4.0 & 0.0 & 5 \\
\hline Phonological Awareness Test - Total & 26.35 & 9.94 & 28.0 & 40 & 0.0 & 66 \\
\hline
\end{tabular}

One possibility may be suggested to explain the greater development of the syllabic abilities than the phonemic abilities: the syllables are the more audible and easily perceived units of the speech, therefore, they are simpler to distinguish than the phonemes and thus easier to manipulate.

Considering the phonemic abilities, the lowest scores were obtained in the tasks involving transposition and phonemic segmentation. As phonological awareness is acquired in an interdependent relationship with reading and writing, it is possible that children in the initial phase of the acquisition of reading and writing present difficulties in mastering the phonemic abilities. The results are similar to the findings of Freitas (2008).

The BCPR test and the forward and reverse digit span test of the WISC III scale were used for the evaluation of the phonological working memory. Table 2 shows the mean results for both tests. As can be seen, the mean scores presented for the BCPR show that the mean score of the participants was 34 points on the scale. According to Santos and Bueno (2003), this result can be considered as expected for children 6 years of age.

Regarding the digit span, it was observed that the children had greater difficulty remembering digits in reverse order than in direct order, which corresponds to the normative data of Santos and Bueno (2003). According to Gathercole (1998), this difficulty is due to the difference in the ability required for the processing of the tasks. The repetition of digits in the forward order evaluates the phonological loop and, in backward order evaluates the central executive (attention control), as to repeat any item in the inverse form it is necessary for the individual to retain such items for a few moments, manipulate them, reverse the order, and reproduce them.

The same difficulty in manipulating elements can also be seen in the phonological awareness tests (Table 1), where the participants presented regular performance in the syllabic transposition subtest and low performance in the phonemic transposition subtest. Gathercole (1998) mentions that children are able to manipulate elements in backward order deftly from the age of seven, when the memory process is consolidated, with the results of the backward order digit span test indicating that the children evaluated had partially mastered this task, which was appropriate for their age.

By correlating the scores obtained from the phonological awareness and phonological working memory tests, it was observed that both are strongly associated with each other, as can be seen in Table 3. Results such as these have also been observed by Gathercole (1998). However, when analyzing correlations between different phonological awareness abilities and the phonological working memory abilities, it is possible to observe a variation in the level of correlation between them. Suprasegmental abilities showed weaker correlations with the phonological working memory abilities, which may indicate that they are not directly related to the memory abilities. This tenuous relationship between suprasegmental abilities and phonological working memory may be related to the nature of the task, because, according to Lundberg et al. (1988), the suprasegmental tasks relate to the identification of the initial or final syllables or phonemes in the words, i.e. comparison tasks, for which the working memory ability may be minimally required. 
Bandini, H. H. M., Santos, F. H., \& de Souza, D. G. (2013). Phonological Awareness, Memory and Lexical Knowledge.

Table 2

Mean Scores of Phonological Working Memory Abilities for the BCPR and Digit Span Tests, Standard Deviation, Median, Maximum and Minimum Scores, and Mean of Correct Responses $(n=254)$ in Study 1

\begin{tabular}{|c|c|c|c|c|c|c|}
\hline & Mean & $\begin{array}{c}\text { Standard } \\
\text { Deviation }\end{array}$ & Median & Maximum & Minimum & $\begin{array}{l}\text { Mean of Correct } \\
\text { Responses }(\%)\end{array}$ \\
\hline \multicolumn{7}{|l|}{ BCPR } \\
\hline Total & 34.2 & 5.3 & 35.0 & 40 & 14 & 85 \\
\hline Low Similarity to Words & 8.8 & 1.5 & 10.0 & 10 & 3 & 88 \\
\hline Medium Similarity to Words & 16.5 & 3.2 & 17.0 & 20 & 2 & 82.5 \\
\hline High Similarity to Words & 8.9 & 1.6 & 10.0 & 10 & 2 & 89 \\
\hline \multicolumn{7}{|l|}{ Digit Span } \\
\hline Forward Order & 5.1 & 0.95 & 5 & - & 3 & - \\
\hline Backward Order & 2.9 & 1.18 & 2 & - & 0.0 & - \\
\hline
\end{tabular}

The results indicate a positive correlation between the BCPR and the digit span (Table 3), which supports the findings described by Santos and Bueno (2003), demonstrating that the two tests can be used to obtain reliable results with regard to the evaluation of the phonological working memory of children between five and seven years of age. Study 1 showed that there are distinct levels of development of specific phonological awareness abilities and that the syllabic and phonemic abilities seem to be more dependent on the phonological working memory abilities than the suprasegmental abilities. Study 1 also assists in the presentation of complementary normative data between the BCPR and the forward and backward digit span test of the WISC III intelligence scale.

Table 3

Correlations Between the Scores in the Phonological Awareness, Forward and Backward Digit Span and the BCPR Tests in Study 1

\begin{tabular}{|c|c|c|c|c|}
\hline \multirow{3}{*}{ Phonological Awareness } & & \multicolumn{3}{|c|}{ Phonological Working Memory } \\
\hline & & \multicolumn{2}{|c|}{ Digit Span } & \multirow{2}{*}{ BCPR } \\
\hline & & Forward Order & Backward Order & \\
\hline Phonological Awareness - Total & - & $.32 * * *$ & $.39 * * *$ & $.58 * * *$ \\
\hline Suprasegmental & $.24 * * *$ & .09 & $.12 *$ & $.13^{*}$ \\
\hline Syllabic & $.86^{* * *}$ & $.33 * * *$ & $.35 * * *$ & $.51 * * *$ \\
\hline Phonemic & $.94 * * *$ & $.291 * * *$ & $.40 * * *$ & $.54 * * *$ \\
\hline Forward Order Digit Span & - & - & $.19 * *$ & $.49 * * *$ \\
\hline Backward Order Digit Span & - & - & - & $.44 * * *$ \\
\hline
\end{tabular}

${ }^{*} p<.05 . * * p<.01 . * * * p<.001$.

\section{Participants}

\section{Method - Study 2}

The sample was comprised of 12 children aged between 6 years and 6 years and 7 months $(M=6$ years and 3 months), all participants of Study 1. The participants were selected according to the total scores presented in the phonological awareness and phonological working memory tests and were divided into two groups: Group A was composed of children with high scores in phonological awareness (score equal to or greater than 36 points in the PAT) and phonological working memory (scores equal to or greater than 34 points in the BCPR), and Group B was composed of children with low scores in phonological awareness (score equal to or less than 10 points in the PAT) and phonological working memory (scores equal to or less than 30 points in the BCPR). The following parameters were used as the selection criteria of the score for the composition of the groups: for Group A, participants with higher scores within the normal limits for the age; for Group $\mathrm{B}$, the minimum normal values for the age in both tests were considered. Table 4 presents the phonological awareness and phonological working memory mean scores for each group.

\section{Instruments}

ABFW Language Evaluation (Andrade, Béfi-Lopes Fernandes, \& Wertzner, 2004), which aimed to obtain data regarding the levels of language development. For Study 2, only the expressive vocabulary and fluency evaluations were used. The Expressive Vocabulary Evaluation covers nine semantic categories (clothing, animals, food, transportation, furniture and utensils, professions, places, shapes and colors, 
and toys). The task consists of the naming of 118 color figures, presented on cards grouped by semantic categories. For the vocabulary test, three measures for the nine semantic categories evaluated were considered: (a) usual verbal designation, for correct answers; (b) process of substitution of answers, by means of synonyms or information regarding the function of the object; (c) no verbal designation, for answers that indicated that the child was unaware of the figure.

Table 4

Mean and Standard Deviation for the Phonological Awareness and Phonological Working Memory Tests for Each of the Groups in Study 2

\begin{tabular}{lcccc}
\hline & \multicolumn{2}{c}{ Group A } & \multicolumn{2}{c}{ Group B } \\
\cline { 2 - 5 } & Mean & $\begin{array}{c}\text { Standard } \\
\text { Deviation }\end{array}$ & Mean & $\begin{array}{c}\text { Standard } \\
\text { Deviation }\end{array}$ \\
\hline Phonological Awareness & & & & \\
$\quad$ Suprasegmental & 8.0 & 0.0 & 2.0 & 2.33 \\
$\quad$ Syllabic & 16.0 & 0.0 & 6.0 & 2.78 \\
$\quad$ Phonemic & 12.0 & 0.0 & 0.0 & 0 \\
$\quad$ Total & 36.0 & 0.0 & 5.0 & 4.5 \\
$\quad$ Total Average & 90.0 & - & 12.5 & - \\
Phonological Working & & & & \\
Memory & 10 & 1.21 & 6.0 & 1.32 \\
$\quad$ Forward Order Digit & & & & \\
$\quad$ Span & 4 & 1.61 & 0.0 & 0.81 \\
$\quad$ Backward Order Digit & & & & \\
$\quad$ Span & 39.0 & 0.98 & 24.1 & 5.00 \\
$\quad$ BCPR & 97.5 & - & 60.0 & - \\
$\quad$ Mean &
\end{tabular}

Note. The groups were composed from the data obtained in the phonological awareness and BCPR tests. The maximum points allowed for the suprasegmental ability tests was 08 points and for the syllabic and phonemic abilities tests 16 points.

For the Fluency Evaluation, a single figure with a leisure situation scene (children's party) was presented to the participants, who were instructed to describe what they saw. The scores are measured by the words rate (words/minute). In both cases, the scores obtained by the participants were compared with the standards established for the age by the ABFW (Andrade et al., 2004).

\section{Procedure}

Data collection. The children were evaluated individually, in a single session, in the school where they studied, during the class period. The session was recorded as audio files for later analysis. The test tasks were presented in the same way as in Study 1.

Data analysis. For the data analysis, the students who presented high scores in the working memory and phonological awareness abilities evaluations and those who presented low scores in both measures were considered separately.

\section{Results and Discussion}

As can be seen in Figure 1, all the participants in Group A presented a high degree of usual designation of the items (left columns) and therefore their results were better than expected for the age (by comparison of the bars with the normative lines) and none of them failed to respond or employed word substitution. The performances of the participants of Group B also consisted predominantly of usual designations, however, with scores lower than expected for the age in several categories, especially in the place (category 7, $n=6$ ), clothing (category $1, n=4$ ), food (category $3, n=4$ ), and shapes and colors (category $8, n=2$ ) categories. Responses differing from the usual designation consisted, in most cases, of substitutions (middle columns), however, cases of no response were also observed (right columns). According to Andrade et al. (2004), high scores for no verbal designation are not expected for participants aged 6 years. Thus, these findings point to a flaw in vocabulary construction, indicating problems in the language development of the Group B children.

The participants of Group A presented word emission rates (words/minute) as expected for the age (less than 70 words/minute, according to Andrade et al., [2004]), while all the participants of Group B presented much lower scores (20 to 40 words/minute), with the exception of participant 12 , where the rate approached 70 words/minute. It was therefore observed that all the participants of Group B presented scores lower than expected for the age, both in vocabulary and fluency (word and syllable emission rates).

Although the number of participants was small, implying a limitation in generalizing the data found, it is possible to verify that the scores presented by the participants of Group B, in both language measures, were considerably lower compared to the scores obtained by the participants of Group A (Figure 1), and compared to the standards established by the test as appropriate for the age of the participants. Based solely on these measures, it cannot be affirmed that the children evaluated in Group $\mathrm{B}$ presented specific language disorders. However, it is possible to verify that their language development was less than expected for the age. These changes may be related to various factors, among them deficient opportunities for learning caused by poor stimulatory environments due to the socioeconomic level, as demonstrated by Engel et al. (2008) and McDowell et al. (2007).

As can be seen in Table 4, the working memory ability results presented by the participants of Group B for the tasks that directly involved the evaluation of the phonological loop (forward order digit span and the BCPR) were lower than those presented by Group A which contributes positively to the hypothesis of the phonological loop being a structure of the phonological memory mechanism which is highly involved in the process of oral language acquisition (Baddeley, 2003; Fukuda et al., 2010; Kibby, 2009). Regarding the tasks involving the central executive (backward order digit span), it was observed that both groups presented lowered scores, indicating that this ability is not fully consolidated for this age group, as shown by Gathercole (1998). 
Bandini, H. H. M., Santos, F. H., \& de Souza, D. G. (2013). Phonological Awareness, Memory and Lexical Knowledge.
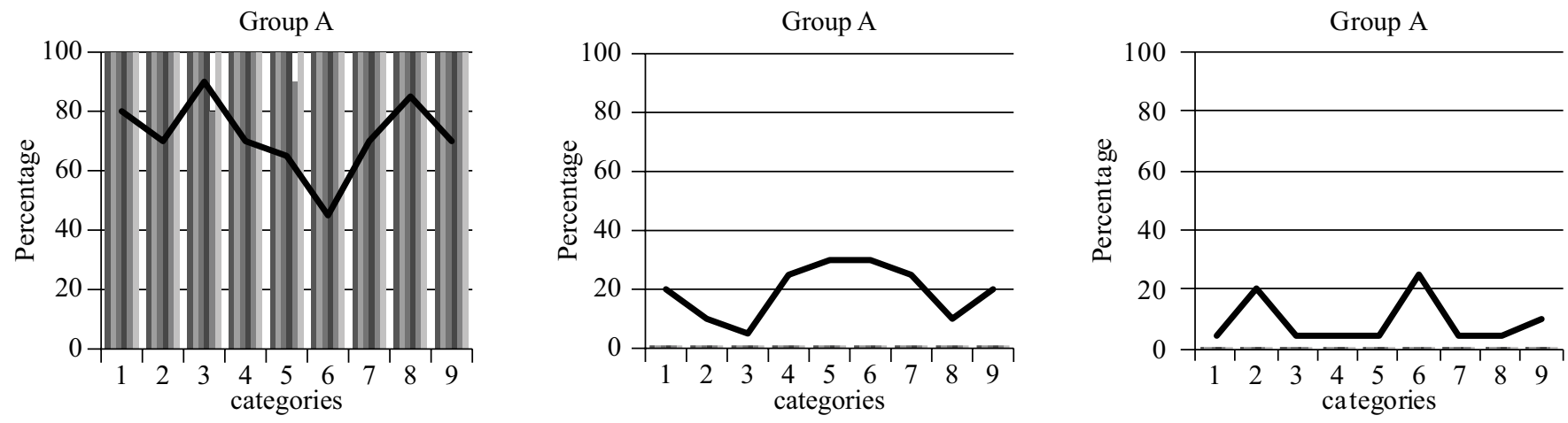

P1
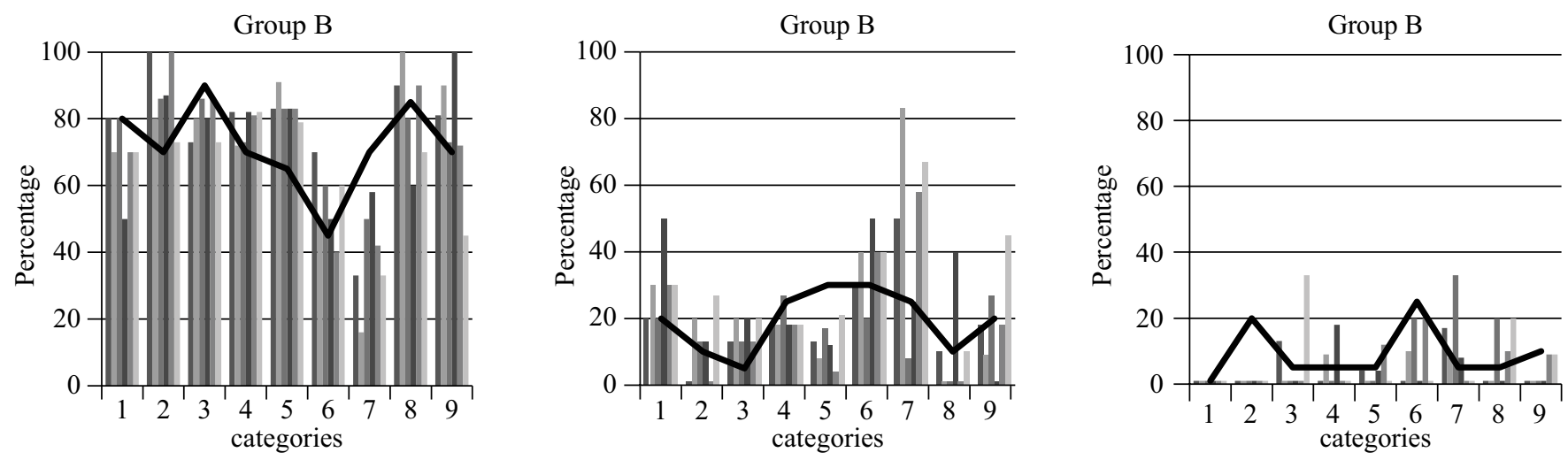

P7

P8 $\square$ P9

P10

P11

P12

Figure 1. Distribution of usual verbal designation, substitution process, and no verbal designation scores for the participants of study 2 , by semantic category. The bars represent the data of the participants and the lines represent the maximum error permitted for the age group of the participants. Categories: 1 - clothing; 2 - animals; 3 - food; 4 - transport; 5 - furniture; 6 - professions; 7 - places; 8 - shapes and colors; and 9- toys.

An important point to note is that the phonological awareness, phonological working memory and language abilities seem to be mutually related, since, when the phonological awareness and phonological working memory scores were high, the language scores were also elevated. Conversely, low language scores were observed only when the phonological awareness and phonological working memory scores were low.

The design of Study 2 does not allow causal effects to be demonstrated between the abilities evaluated. However, it is possible to infer from the literature data (Fukuda et al., 2010; Rispens \& Parigger, 2010), that probable phonological memory difficulties caused language difficulties and that these memory difficulties may also have contributed to difficulties in the mastery of phonological awareness abilities for the children of Group B.

\section{Conclusion}

This article presents contributions for both the conceptual (Study 1) and the methodological fields (Study 2). From a conceptual standpoint, a close association was found between the various levels of phonological awareness and phonological working memory abilities. However, it is important to note that the Phonological Awareness Test used, as described, requires a lot from the working memory abilities, since the words to be manipulated do not have visual support. It would be interesting to investigate phonological awareness using a test that imposes less demands on the working memory, for example, a phonological awareness test supported by the use of figures. From the methodological perspective, it was noted that the evaluation of expressive language, carried out using the ABFW, is sensitive to changes in phonological awareness, detected by the Phonological Awareness Test, and in phonological working memory, verified with the joint use of the memory evaluation composed of the digit tests of the WISC III and BCPR.

A limitation of this study concerns the small sample size for investigating the influence of the phonological awareness and phonological working memory levels in the oral language mastery of school age children. The complexity of the evaluation of expressive language prevented the recruitment of a greater number of participants, however, the data suggest that the relationship between the abilities covered in this article should be the object of a systematic investigation. 


\section{References}

Alloway, T. P., Gathercole, S. E., Willis, C., \& Adams, A.M. (2004). A structural analysis of working memory and related cognitive abilities in young children. Journal of Experimental Child Psychology, 87(2), 85106. doi:10.1016/j.jecp.2003.10.002

Andrade, C. R. F., Béfi-Lopes, D. M., Fernandes, F. D. M., \& Wertzner, H. F. (2004). ABFW: Teste de linguagem infantil nas áreas de fonologia, vocabulário, fluência e pragmática (2nd ed.).Barueri, SP: Pró-Fono.

Baddeley, A. (2003). Working memory and language: An overview. Journal of Communication Disorders, 36(3), 189-208. doi:10.1016/S0021-9924(03)00019-4

Bernardino Junior, J. A., Freitas, F. R., Souza, D. G., Maranhe, E. A., \& Bandini, H. H. M. (2006). Aquisição de leitura e escrita como resultado do ensino de habilidades de consciência fonológica. Revista Brasileira de Educação Especial, 12(3) 423-450. doi:10.1590/S1413-65382006000300009

Capovilla, A. G. S., \& Capovilla, F. C. (1998). Prova de consciência fonológica: Desenvolvimento de dez habilidades da pré-escola à segunda série. Temas sobre Desenvolvimento, 7(37), 14-20.

Chiappe, P., Glaeser, B., \& Ferko, D. (2007). Speech perception, vocabulary, and development of reading abilities in English among Korean- and Englishspeaking children. Journal of Educational Psychology, 99(1), 154-166. doi:10.1037/0022-0663.99.1.154

Engel, P. M. J., Santos, F. H., \& Gathercole, S. E. (2008). Are working memory measures free of socio-economic influence? Journal of Speech, Language, and Hearing Research, 51(6), 1580-1587.

Freitas, F. R. (2008). Desenvolvimento de habilidades de consciência fonológica: Independência $e$ interdependência funcional no repertório de leitores iniciantes (Unpublished master's thesis). Universidade Federal de São Carlos, São Carlos, SP.

Fukuda, M. T. H., Kutscher, K., Frizzo, A. C. F., Isaac, M. L., Fernandes, R. M. F., \& Funayama, C. A. R. (2010). Characterization of language and phonological working memory in patients with myoclonic astatic epileptic syndrome. Arquivos de Neuro-Psiquiatria, 68(1), 3034. doi:10.1590/S0004-282X2010000100007

Gathercole, S. E. (1998). The development of memory. Journal of Child Psychology and Psychiatry, 39(1), 3-27. doi:10.1017/S0021963097001753

Holliman, A. J., Wood, C., \& Sheehy, K. (2010). Does speech rhythm sensitivity predict children's reading ability 1 year later? Journal of Educational Psychology, 102(2), 356-366. doi:10.1037/a0018049

Kibby, M. Y. (2009). There are multiple contributors to the verbal short-term memory deficit in children with developmental reading disabilities. Child Neuropsychology, 15(5), 485-506. doi:10.1080/09297040902748218
Koo, D., Crain, K., LaSasso, C., \& Eden, G. F. (2008). Phonological awareness and short-term memory in hearing and deaf children individuals of different communication backgrounds. Annals of the New York Academy of Sciences, 1145, 83-99. doi:10.1196/ annals.1416.025

Lundberg, I., Frost, J., \& Petersen, O.-P. (1988). Effects of an extensive program for stimulating phonological awareness in preschool children. Reading Research Quarterly, 23(3), 262-284.

McDowell, K. D., Lonigan, C. J., \& Goldstein, H. (2007). Relations among socioeconomic status, age, and predictors phonological awareness. Journal of Speech, Hearing and Language Research, 50(4), 1079-1092. doi:10.1044/1092-4388 (2007/075)

Mota, M. M. P. E., \& Guimarães, S. B. (2011). Leitura contextual e o processamento metalinguístico: Consideraçõesteóricas.Paidéia(RibeirãoPreto), 21(49), 279-283. doi:10.1590/S0103-863X2011000200016

Oakhill, J., \& Kyle, F. (2000). The relation between phonological awareness and working memory. Journal of Experimental Child Psychology, 75(2), 152-164. doi:10.1006/jecp.1999.2529

Peeters, M., Verhoeven, L., de Moor, J., \& van Balkom, H. (2009). Importance of speech production for phonological awareness and word decoding: The case of children with cerebral palsy. Research in Developmental Disabilities, 30(4), 712-726. doi:10.1016/j.ridd.2008.10.002

Rispens, J., \& Parigger, E. (2010). Non-word repetition in Dutch-speaking children with specific language impairment with and without reading problems. British Journal Developmental Psychology, 28(1), 177-188. doi:10.1348/026151009X482633

Santos, F. H., \& Bueno, O. F. (2003). Validation of the Brazilian Children's Test of Pseudoword Repetition in Portuguese speakers aged 4 to 10 years. Brazilian Journal of Medical and Biological Research, 36(11), 1533-1547. doi:10.1590/S0100-879X2003001100012

Santos, F. H., Bueno O. F., \& Gathercole, S. E. (2006). Errors in nonword repetition: Bridging short- and long-term memory. Brazilian Journal of Medical and Biological Research, 39(3), 371-385. doi:10.1590/ S0100-879X2006000300008

Schuchardt, H., Maehler, C., \& Hasselhorn, M. (2008). Working memory deficits in children with specific learning disorders. Journal of Learning Disabilities, 41(6), 514-523. doi:10.1177/0022219408317856

Swanson, H. L., Zheng, X., \& Jerman, O. (2009). Working memory, short-term memory, and reading disabilities: A selective meta-analysis of the literature. Journal of Learning Disabilities, 42(3), 260-287. doi:10.1177/0022219409331958 
Wechsler, D. (1991). Manual for the Wechsler Intelligence Scale for Children - WISC III (3rd ed.). San Antonio, TX: Psychological Corporation.

Heloisa Helena Motta Bandini is an Associate Professor of the Universidade Estadual de Ciências da Saúde de Alagoas.

Flávia Heloisa Santos is an Assistant Professor of the Universidade Estadual Paulista “Júlio de Mesquita Filho", Assis-SP.

Deisy das Graças de Souza is a Full Professor of the Universidade Federal de São Carlos.

Received: Apr. $23^{\text {rd }} 2012$

$1^{\text {st }}$ Revision: Aug. $22^{\text {nd }} 2012$

$2^{\text {nd }}$ Revision: Nov. $21^{\text {st }} 2012$

Approved: Dec. $4^{\text {th }} 2012$

How to cite this article:

Bandini, H. H. M., Santos, F. H., \& de Souza, D. G. (2013). Levels of phonological awareness, working memory, and lexical knowledge in elementary school children. Paidéia (Ribeirão Preto), 23(56), 329-337. doi:10.1590/1982-43272356201307 


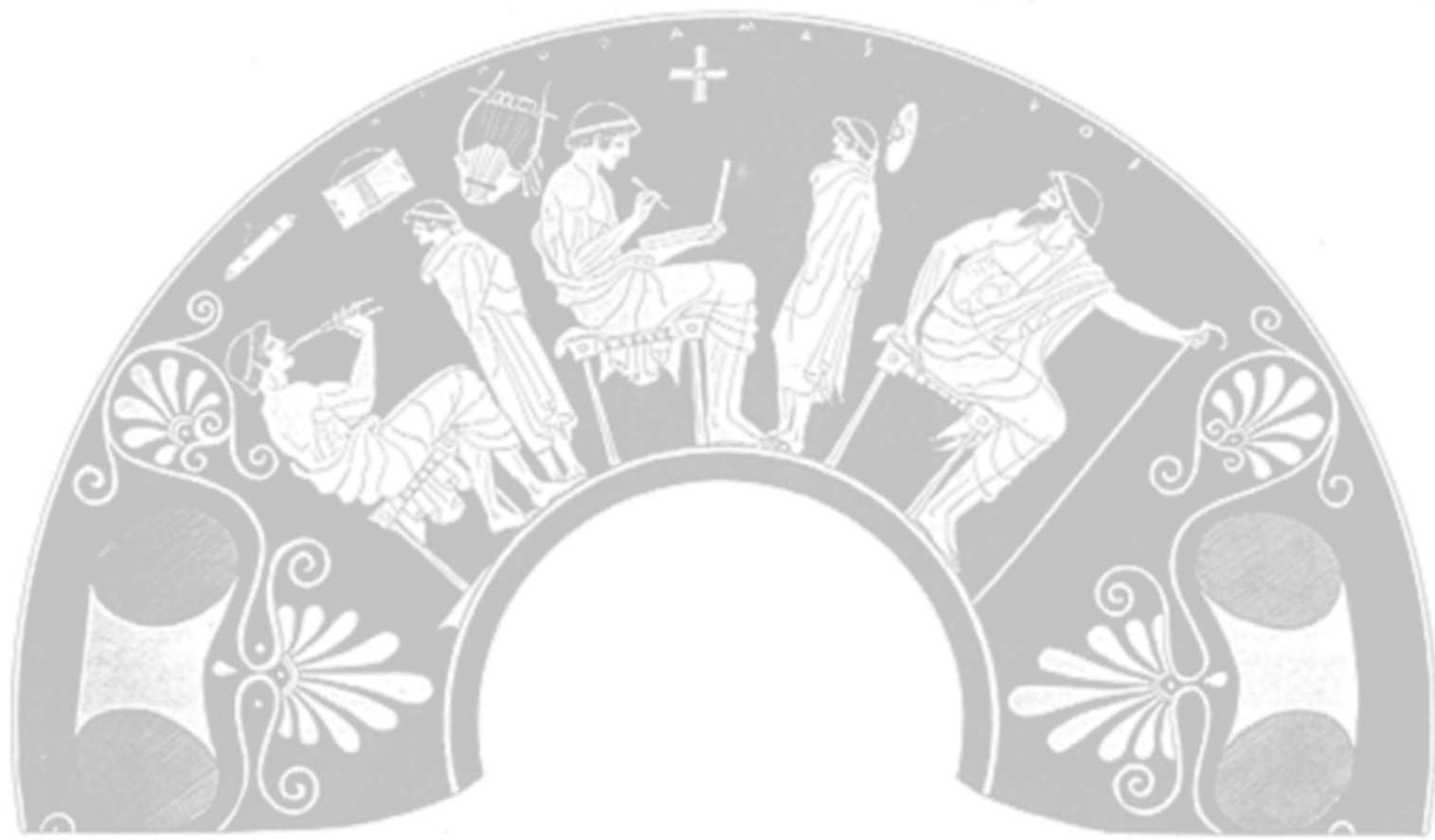

